\title{
GAMBARAN PENGETAHUAN DAN SIKAP MASYARAKAT TENTANG PEMAKAIAN GIGI TIRUAN DI DESA MAYANG PONGKAI KECAMATAN KAMPAR KIRI TENGAH KABUPATEN KAMPAR
}

\author{
Yeyen Gumayesty \\ Program Studi D-III Teknik Gigi STIKes Hang Tuah Pekanbaru \\ e-mail: yeyenrangkuti@gmail.com
}

\begin{abstract}
Denture is a removable dental prosthesis which replaces the masticatory surface and accompanying structures of an upper arch and lower jaw. The function of dentures is the esthetic function recovery, which still lags tissue preservation, prevention of migration of teeth, chewing load distribution improvement. Denture should be kept clean to prevent further tooth loss, gingival inflammation or infection of bacteria and fungi and prevents the denture does not smell.

The aim of research to describe the behavior of the public about the use of denture in Mayang Pongkai Village. Type a descriptive quantitative research. The population is the entire community of Mayang Pongkai Village Central Kampar Kiri with population 2663 people with a sample of 96 respondents. Sampling technique using stratified sampling. Analysis of the data used to describe the univariate independent and dependent variables are presented in the form of a frequency distribution. The research result most respondents did not wear a denture that is 70 respondents (72.9\%), most of the respondents had a good knowledge ie 19 respondents (73.1\%) and the majority of respondents have a negative attitude were 19 respondents (73\%). Suggestions research is expected to generate awareness for the community to create dentures to dental health professionals are dentists who have partnered with dental techniques. Local health workers to conduct counseling on the risks of making dentures in non-health personnel and strive provide affordable dental care to the community.
\end{abstract}

Key words: Denture, Knowledge and Attitudes.

\section{PENDAHULUAN}

Gigi tiruan adalah sebagai protesa gigi lepasan yang berfungsi untuk mengantikan permukaan pengunyahan dan struktur-struktur yang menyertai dari suatu lengkung rahang atas dan rahang bawah. Fungsi gigi tiruan pemulihan fungsi estetik, pelestarian jaringan yang masih tertinggal, pencegahan migrasi gigi, peningkatan distribusi beban kunyah (Haryanto,1995).

Menurut data Riskesdas 2013, persentase penduduk yang mempunyai masalah gigi dan mulut di Indonesia sebesar $25,9 \%$, dan yang menerima perawatan medis di Indonesia sebesar $31,1 \%$, persentase masalah gigi dan mulut yang tertinggi terdapat pada kelompok usia produktif yaitu umur35-44 tahun dan 45-54 tahun. Penduduk Riau yang tertinggi terdapat pada usia 35-44 tahun dan 45-54 tahun, sebesar $16,2 \%$ serta proporsi menyikat gigi setiap hari Kampar menepati urutan ke tiga (3) sebesar 97,6\%.

Pada survey pendahuluan yang peneliti lakukan pada 266 orang terdapat penduduk yang menggunakan gigi tiruan sebanyak 46 orang $(17,3 \%)$ dan yang tidak menggunakan gigi tiruan 220 orang $(82,7 \%)$ dan pengetahuan masyarakat kurang tentang pemakaian gigi tiruan sebanyak 80 orang (30\%). Masyarakat pengguna gigi tiruan di desa Mayang Pongkai memiliki tingkat pendidikan yang berbeda-beda dan keadaan status sosial ekonomi yang tergolong menengah kebawah. Dari hasil wawancara dan observasi dengan masyarakat desa Mayang Pongkai tersebut, didapatkan bahwa pengetahuan masyarakat tentang gigi tiruan masih kurang, hal ini dibuktikan dengan adanya gigi tiruan yang patah tapi disambung sendiri menggunakan benang, protesa sudah berubah warna, dan oral hygene tidak baik. Jasa pembuatan gigi tiruan yang dipakai oleh masyarakat tersebut lebih banyak ke tukang gigi keliling dan masyarakat yang tidak menggunakan gigi tituan, merasa malu memakai gigi tiruan, jijik memakai gigi tiruan karena masyarakat mengira gigi tiruan terbuat dari gigi hewan. 


\section{METODOLOGI PENELITIAN}

Jenis penelitian yang digunakan adalah kuantitatif yang bersifat deskriptif. Penelitian dilaksanakan pada bulan Mei sampai bulan Juli 2016. Populasi dalam penelitian ini adalah seluruh Masyarakat Desa Mayang Pongkai Kecamatan Kampar Kiri Tengah Kabupaten Kampar yang berjumlah 2663 orang. Sampel pada penelitian ini adalah sebagian masyarakat Desa Mayang Pongkai Kecamatan Kampar Kiri Tengah Kabupaten Kampar Tahun 2016 berjumlah 96 responden. Teknik sampling yang digunakan dalam penelitian ini stratified sampling (propportional sampling). Pengambilan secara proporsi dilakukan dengan mengambil subyek dari setiap RT ditentukan seimbang dengan banyaknya subyek dalam masing-masing RT di Desa Mayang Pongkai.

Data primer diperoleh langsung dari responden melalui kuesioner yang dibuat oleh peneliti dan responden mengisi sendiri lembaran kuesioner yang telah disediakan. Data sekunder yaitu data yang diperoleh dari penelusuran dokumen yang bersumber dari Kantor Kepala Desa Kecamatan Kampar Kiri Tengah Kabupaten Kampar.

\section{HASIL DAN PEMBAHASAN \\ Hasil \\ Karakteristik Responden \\ a. Umur}

Tabel 3.1

Distribusi Frekuensi Responden Berdasarkan Umur

\begin{tabular}{cccc}
\hline No & Umur & $\begin{array}{c}\text { Frekuensi } \\
\text { (Orang) }\end{array}$ & Persentase \\
\hline 1 & $35-40$ & 56 & 58.3 \\
2 & $41-44$ & 40 & 41.7 \\
\hline Total & & 96 & 100 \\
\hline
\end{tabular}

b. Jenis Kelamin

Tabel 3.2

Distribusi Frekuensi Responden BerdasarkanJenis Kelamin

\begin{tabular}{clcc}
\hline No & $\begin{array}{c}\text { Jenis } \\
\text { Kelamin }\end{array}$ & $\begin{array}{c}\text { Frekuensi } \\
\text { (Orang) }\end{array}$ & Persentase \\
\hline 1 & Laki-laki & 39 & 40.6 \\
2 & Perempuan & 57 & 59.4 \\
\hline Total & & 96 & 100 \\
\hline
\end{tabular}

c. Pendidikan

Tabel 3.3

Distribusi Frekuensi Responden Berdasarkan Pendidikan

\begin{tabular}{clcc}
\hline No & Pendidikan & $\begin{array}{c}\text { Frekuensi } \\
\text { (Orang) }\end{array}$ & Persentase \\
\hline 1 & Tidak & 29 & 30.2 \\
& Tamat & & \\
2 & SD & 23 & 24.0 \\
3 & SMP & 14 & 14.6 \\
4 & SMA & 19 & 19.8 \\
5 & Perguruan & 11 & 11.5 \\
& Tinggi & & \\
\hline Total & & 96 & 100 \\
\hline
\end{tabular}

d. Pekerjaan

Tabel 3.4

Distribusi Frekuensi Responden Berdasarkan Pekerjaan

\begin{tabular}{clcc}
\hline No & \multicolumn{1}{c}{ Pekerjaan } & $\begin{array}{c}\text { Frekuens } \\
\text { i (Orang) }\end{array}$ & $\begin{array}{c}\text { Persentas } \\
\text { e }\end{array}$ \\
\hline 1 & IRT & 14 & 14.6 \\
2 & Tani & 36 & 37.5 \\
3 & Swasta & 17 & 17.7 \\
4 & Pelajar/mahasisw & 9 & 9.4 \\
& a & & \\
5 & PNS & 20 & 20.8 \\
\hline Tota & & 96 & 100 \\
1 & & & \\
\hline
\end{tabular}

e. Ekonomi

Tabel 3.5

Distribusi Frekuensi Responden Berdasarkan Ekonomi 3

\begin{tabular}{llcc}
\hline No & Ekonomi & $\begin{array}{l}\text { Frekuensi } \\
\text { (Orang) }\end{array}$ & Persentase \\
\hline 1 & $(\mathrm{Rp}$. & 14 & 14.6 \\
& $\begin{array}{l}1.500 .000) \\
(\mathrm{Rp} .\end{array}$ & 24 & 25.0 \\
& $\begin{array}{l}2.500 .000) \\
(\mathrm{Rp} .\end{array}$ & 58 & 60.4 \\
& $3.500 .000)$ & & 100 \\
\hline Total & & 96 & \\
\hline
\end{tabular}

f. Pemakaian Gigi Tiruan Tabel 3.6

Distribusi Frekuensi Responden Berdasarkan Pemakaian Gigi Tiruan

\begin{tabular}{clcc}
\hline No & $\begin{array}{c}\text { Pemakaian } \\
\text { Gigi Tiruan }\end{array}$ & $\begin{array}{c}\text { Frekuensi } \\
\text { (Orang) }\end{array}$ & Persentase \\
\hline 1 & Tidak & 70 & 72.9 \\
& Memakai & & \\
2 & Memakai & 26 & 27.1 \\
\hline Total & & 96 & 100 \\
\hline
\end{tabular}




\section{g. Pengetahuan}

Tabel 3.7

Distribusi Frekuensi Responden Berdasarkan Pengetahuan

\begin{tabular}{clcl}
\hline No & Pengetahuan & $\begin{array}{c}\text { Frekuensi } \\
\text { (Orang) }\end{array}$ & Persentase \\
\hline 1 & Kurang Baik & 10 & 10.4 \\
2 & Baik & 86 & 90 \\
\hline Total & & 96 & 100 \\
\hline
\end{tabular}

h. Sikap

Distribusi Frekuensi Responden Berdasarkan Sikap

\begin{tabular}{llcc}
\hline No & Sikap & $\begin{array}{c}\text { Frekuensi } \\
\text { (Orang) }\end{array}$ & Persentase \\
\hline 1 & Negatif & 77 & 80.2 \\
2 & Positif & 19 & 19.8 \\
\hline Total & & 96 & 100 \\
\hline
\end{tabular}

\section{Pembahasan}

\section{Karakteristik Responden}

a. Umur

Hasil penelitian menunjukkan bahwa 56 orang responden $(58.3 \%)$ terdapat pada kelompok usia 35-40 tahun yang tidak pakai gigi tiruan 41 orang dan yang pakai gigi tiruan 15 orang.

Berdasarkan hasil penelitian yang dilakukan oleh Vlorenzy (2015) menunjukkan bahwa sebagian besar responden berada pada kelompok usia 51 - 60 tahun yaitu sebanyak 16 responden $(53,33 \%)$ paling banyak didapati mengalami kehilangan gigi dan yang menggunakan gigi tiruan sebagian lepasan. Hasil penelitian tersebut sesuai dengan penelitian Lin et al yang menyatakan lebih dari $90 \%$ seseorang berusia 60 tahun ke atas telah mengalami kehilangan gigi karena telah dicabut ataupun indikasi untuk dicabut.

Hal ini didukung oleh teori Notoatmodjo (2007) bahwa umur adalah mempengaruhi daya tangkap dan pola pikir seseorang. Semakin bertambah umur semakin berkembang pula daya tangkap dan pola pikirnya, sehingga pengetahuan yang di peroleh semakin membaik.

Berdasarkan asumsi peneliti sesuai dengan karakteristik umur menunjukkan bahwa persentase pemakaian gigi tiruan pada usia lanjut lebih banyak karena dimana usia lanjut lebih mengalami kemunduran fisik.

\section{b. Jenis Kelamin}

Hasil penelitian menunjukkan bahwa responden perempuan lebih banyak dari pada lak-laki, hal ini menunjukkan lebih di dominasi oleh perempuan sebanyak 57 responden (59.4\%), dibandingkan responden berjenis kelamin laki-laki 39 responden $(40.6 \%)$.

Sesuai dengan penelitian yang dilaporkan oleh Prabhu et al. yaitu Persentase penggunaan gigi tiruan sebagian lepasan berdasarkan jenis kelamin, lebih besar didapati pada jenis kelamin perempuan dibandingkan laki-laki. Beberapa penelitian menunjukkan perempuan lebih beresiko mengalami kehilangan gigi dibandingkan laki-laki dikarenakan berkurangnya kadar hormon estrogen yang menyebabkan tulang kehilangan kalsium yang terdapat juga pada gigi.

Berdasarkan asumsi peneliti berdasarkan karakteristik jenis kelamin perempuan lebih mayoritas dibandingkan laki-laki karena perempuan lebih mementingkan penampilan ketika memakai gigi tiruan dan perempuan lebih peduli terhadap perawatan gigi dari pada laki-laki, sehingga lebih ingin untuk memakai gigi tiruan termasuk non propesional ataupun keperawat untuk memasang gigi tiruan.

\section{c. Pendidikan}

Hasil penelitian menunjukkan bahwa responden sebagian besar pendidikannya adalah Tidak Tamat yaitu 29 responden (30.2\%) sedangkan yang paling rendah adalah pendidikan PT (Perguruan Tinggi) yaitu 11 responden $(11.5 \%)$.

Berdasarkan hasil penelitian yang dilakukan oleh Jatuadomi dkk (2016), menunjukkan bahwa responden yang menempuh tingkat pendidikan SMA merupakan pasien dengan jumlah terbanyak 18 orang $(56,25 \%)$.

Seseorang yang memiliki pendidikan yang lebih tinggi, lebih banyak mendapatkan informasi tentang kebutuhan kesehatan sehingga dapat mencari perawatan gigi lebih awal dibandingkan dengan seseorang yang 
memiliki status pendidikan rendah (Esan TA $\mathrm{dkk}, 2014)$.

Penulis berasumsi bahwa pendidikan penting, hal tersebut memengaruhi pengetahuan mereka terhadap penggunaan gigi tiruan sebagian lepasan karena semakin tinggi tingkat pendidikan maka tingkat pengetahuannya akan semakin banyak dengan demikian daya serap terhadap informasi juga akan semakin tinggi.

\section{d. Pekerjaan}

Berdasarkan hasil penelitian menunjukkan bahwa responden dengan jenis pekerjaan petani yaitu 36 responden (37.5\%) sedangkan sebagian kecil pekerjaannya adalah Pelajar/Mahasiswa yaitu 9 responden (9.4\%). Namun hal ini berdampak pada status ekonomi masyarakat dengan biaya yang akan dikeluarkan untuk pembuatan gigi tiruan terhadap pemilihan pembuatan gigi tiruan.

Berdasarkan penelitian yang dilakukan oleh Ibnu Husnul Aulia (2014), menunjukkan bahwa responden dengan jenis pekerjaan tani 48 responden $(52.7 \%)$ lebih banyak dibandingkan dengan responden yang bekerja sebagai seorang PNS. Namun hal ini berdampak pada status ekonomi masyarakat dengan biaya yang akan dikeluarkan untuk pembuatan gigi tiruan terhadap pemilihan tempat pembuatan gigi tiruan.

Penulis berasumsi bahwa pekerjaan akan memperngaruhi masyarakat untuk memasang gigi tiruan karena melihat biaya pembuatan gigi tiruan mahal sehingga masyarakat memilih membuat gigi tiruan ke tukang gigi karena relatif lebih murah. Terhadap masyarakat pekerjaannya tani harus lebih banyak bertanya kepada tenaga medis sebelum memakai gigi tiruan jangan asal pasang saja terutama memasang ke tukang gigi.

\section{e. Ekonomi}

Berdasarkan hasil penelitian menunjukkan bahwa responden dengan mempunyai Ekonomi yang tertinggi pada pendapatan golongan pendapatan tinggi 58 responden (60.4\%), sedangkan sebagian kecil pendapatan yang terendah pada golongan pendapatan rendah 14 responden (14.6\%).
Menurut George Soul, ekonomi adalah pengetahuan sosial yang mempelajari tingkah laku manusia dalam kehidupan masyarakat khususnya dengan usaha memenuhi kebutuhan dalam rangka mencapai kemakmuran dan kesejahteraan (Richard G Lipsey dan Pete O Steiner, 1991).

Penelitian yang dilakukan oleh Sarnizia pada tahun 2008 di Medan menemukan bahwa sebanyak $92,5 \%$ menyatakan biaya yang relatif lebih murah pada tukang gigi menjadi alasan utama dalam memanfaatkan jasa tukang gigi dibandingkan dengan pelayanan kesehatan gigi lainnya dan mengenai biaya pasang gigi palsu yang berlaku menurut tukang gigi umumnya berkisar Rp. 80.000,- sampai Rp. 100.000,tergantung gigi tiruan yang akan dibuatkan bahkan khusus untuk pembuatan gigi tiruan bisa dilakukan cicilan 3 kali sedangkan pada dokter gigi harga yang ditawarkan jauh lebih mahal sesuai dengan kondisi gigi yang akan dibuatkan gigi tiruan dan pasien tidak dapat mencicil. 15 Hasil penelitian tersebut tentu tidak berbeda jauh dengan penelitian yang penulis lakukan di desa Treman tentang pembuatan gigi tiruan oleh tukang gigi lebih murah dibandingkan dokter gigi bahwa responden merasa pembuatan gigi tiruan oleh tukang gigi lebih murah bahkan dapat dicicil sehingga mereka lebih memilih ke tukang gigi untuk melakukan pembuatan gigi tiruan dibandingkan ke dokter gigi karena alasan ekonomi.

Penulis berasumsi bahwa sosial ekonomi yang lemah kebanyakan dari responden lebih mencari harga yang lebih murah ke tukang gigi untuk pembuatan gigi tiruan namun responden tidak memperhatikan kesterilisasi dari alat-alat, bahan-bahan yang digunakan dalam pembuatan gigi tiruan. Memasang gigi jangan dilihat murahnya tapi kualitas dan kesterilisasi alat-alat atau pembuatan gigi tiruan.

\section{Analisis Univariat}

\section{a. Pemakaian Gigi Tiruan}

Berdasarkan hasil dari penelitian menunjukkan bahwa dari 96 responden yang diteliti, sebagian besar responden tidak memakai Gigi Tiruan yaitu 70 responden 
(72.9\%), sedangkan responden yang memakai Gigi Tiruan berjumlah 26 responden (27.1\%).

Penelitian yang dilakukan oleh Fonda Pandu (2014), yaitu sebagian besar responden tahu bahwa perubahan penampilan dapat diperbaiki dengan memakai gigi tiruan. Dengan persentase hampir $90 \%$ menunjukkan bahwa pengetahuan responden mengenai manfaat gigi tiruan yang berhubungan dengan perubahan penampilan tergolong baik. Responden tahu bahwa jika kehilangan gigi maka penampilan mereka akan menjadi tidak menarik karena tidak bisa bebas untuk berbicara atau tersenyum. Hal ini juga berkaitan dengan tujuan pemakaian gigi tiruan yaitu untuk memperbaiki estetik. Seseorang yang mengalami kehilangan gigi namun telah memakai gigi tiruan akan lebih percaya diri untuk berinteraksi dengan orang lain, tidak akan lagi merasa malu atau rendah diri saat berbicara atau tertawa di depan umum.

Penulis berasumsi bahwa masyarakat yang tidak memakai gigi tiruan karena sebagian besar merasa memakai gigi tiruan tidak nyaman memakai gigi tiruan, merasa malu, biaya mahal, jijik atau geli, dan lain-lain. Di harapkan bagi responden yang giginya ompong harus menggunakan gigi tiruan karen kalau tidak segera dipasang akan menyebabkan migrasi, erupsi berlebihan, penurunan efisiensi kunyah dll.

\section{b. Pengetahuan}

Berdasarkan hasil penelitian ini menunjukkan bahwa dari 96 responden sebagian besar responden memiliki pengetahuan Baik yaitu berjumlah 86 responden $(90 \%)$, pengetahuan Kurang Baik yaitu berjumlah 10 responden (10.4\%).

Pengetahuan merupakan salah satu faktor yang berperan dalam proses perkembangan kesehatan sesorang. Semakin banyak pengetahuan seseorang terhadap kesehatan gigi dan mulut, maka semakin baik pula tingkat kesehatan yang dimiliki seseorang (Nursalam Pariani, 2010).

Penelitian ini dilakukan oleh Olivia (2014) menunjukkan bahwa dalam hal pengetahuan masyarakat pengguna gigi tiruan tentang pemakaian gigi tiruan mempunyai dampak buruk pada kebersihan rongga mulut masih kurang, dimana 40 responden menjawab tidak tahu. Hal tersebut menunjukkan bahwa mayoritas masyarakat tidak mengetahui akibatakibat yang dapat terjadi dari pemakaian gigi tiruan antara lain bertambahnya akumulasi plak meningkatnya frekuensi karies, memburuknya kebersihan mulut, radang gingiva dan goyangnya gigi.

Penulis berasumsi bahwa sebagian besar responden memiliki tingkat pengetahuan baik. Berdasarkan pengamatan dilapangan bahwa jika dilihat dari tingkat pendidikan formal yang diperoleh responden, mayoritas pendidikan responden terbanyak adalah SD, SMA, dan PT (Perguruan Tinggi).

\section{c. Sikap}

Berdasarkan hasil penelitian menunjukkan bahwa dari 96 responden sebagian besar responden mempunyai Sikap Negatif yaitu 77 responden $(80.2 \%)$, dan sebagian kecil responden mempunyai sikap Positif yaitu 19 responden (19.8\%). Jadi Sikap responden terhadap Pemakaian Gigi Tiruan kurang baik.

Sikap merupakan reaksi atau respons yang masih tertutup dari seseorang terhadap suatu stimulus atau objek. Newcomb, salah seorang ahli spikologis sosial menyatakan bahwa sikap itu merupakan kesiapan atau kesediaan untuk bertindak, dan bukan merupakan pelaksanaan motif tertentu (Notoatmodjo, 2012).

Penelitian yang dilakukan oleh David (20`4) yaitu berdasarkan skor rata-rata yang diperoleh menunjukkan hasil bahwa sikap masyarakat dalam memelihara gigi tiruan lepasan berbasis akrilik di desa Treman kecamatan Kauditan termasuk dalam kategori baik. Hasil ini menunjukkan bahwa pengguna gigi tiruan lepasan berbasis akrilik di desa Treman mempunyai kesadaran untuk berubah menjadi lebih baik dalam memelihara kebersihan gigi tiruan mereka. Salah satu alasan seseorang menunjukkan sikap yang ingin berubah atau menjadi lebih baik dalam hal kesehatan karena adanya suatu inovasi yang dapat memotivasi responden. Melalui inovasi yang diperoleh seperti program-program kesehatan atau sarana lain yang membantu 
responden dalam hal mendapatkan informasi tentang pemeliharaan kebersihan gigi tiruan serta kesehatan gigi dan mulut khususnya pada pengguna gigi tiruan dan mengadopsi nilai-nilai yang baik dari inovasi tersebut untuk melakukan perubahan.

Penulis berasumsi bahwa sebagian besar responden sikap responden Negatif karena masyarakat kurang memperdulikan perawatan gigi tiruan atau kurang memperhatikan gigi merekat sehingga banyak masyarakat lebih memilih gigi ompong dari pada memakai gigi tiruan itu di pengaruhi juga oleh faktor pengetahuan dan faktor pendidikan. Kesadaran sikap responden yang baik disebabkan oleh setiap responden mempunyai kesediaan untuk berubah. Salah satu alasan seseorang menunjukkan sikap dalam hal memperoleh kesehatan adalah suatu inovasi yang dapat memotivasi responden. Melalui inovasi atau program-program kesehatan, responden mengadopsi nilai-nilai yang baik berkaitan dengan upaya pemeliharaan kesehatan gigi dan mulut, sehingga mereka memiliki kesediaan untuk berubah.

\section{KESIMPULAN}

Berdasarkan hasil penelitian yang di lakukan mengenai Gambaran Perilaku Masyarakat Tentang Pemakaian Gigi Tiruan di Desa Mayang Pongkai Kecamatan Kampar Kiri Tengah Kabupaten Kampar Tahun 2016, maka dapat disimpulkan sebagai berikut:

1. Mayoritas responden berumur 35-40 tahun sebanyak 56 responden (58.3\%), mayoritas responden berjenis kelamin Perempuan 57 responden $(59.4 \%)$, mayoritas pendidikan responden Tidak Tamat SD yaitu 29 responden $(30.2 \%)$, mayoritas pekerjaan Tani yaitu 36 responden (37.5\%), mayoritas pendapatan ekonomi responden golongan pendapatan tinggi $58(60.4 \%)$.

2. Responden memiliki pengetahuan baik dari 96 responden yaitu 86 responden (90\%), dan pengetahuan kurang baik yaitu 10 responden $(10.4 \%)$.
3. Responden memiliki sikap yang Negatif dari 96 responden yaitu 77 responden (80.2\%), dan sikap positif yaitu 19 responden (19.8\%).

\section{DAFTAR PUSTAKA}

Agtini MD. Presentasi pengguna protesa di Indonesia tahun 2010. [diakses 26 April 2013] Available from: URL: http://ejournal.litbang.depkes.go.id/index $\mathrm{php} / \mathrm{MPK} /$ article/download/782/ $\underline{870}$.

Aryani. Pemasangan dan pemeliharaan gigi tiruan. [diakses 26 April 2013] Diunduh dari: URL: http://ocw.usu.ac.id/course/download/61 10000046-

David. 2014. Perilaku Memelihara Kebersihan Gigi Tiruan Lepasan Berbasis Akrilik Pada Masyarakat, Universitas Sam Ratulangi Manado.

Dikbas I, Koksal T, Bal B, Ozkurt Z, Kazaoglu E. A survey of dentists' attitudes toward denture cleansing. Turki 2005; cited 21 Mei 2013]

Fitria. 2014. Gambaran karakteristik individu, pengetahuan, dan Sikap lanjut usia terhadap gigi tiruan di panti lanjut usia khusnul khotimah, Program Studi D-III Teknik Gigi STIKes Hang Tuah Pekanbaru.

Gunadi HA, Margo A, Burhan LK, Suryatenggara F, Setiabudi I, editor. Buku ajar geligi tiruan sebagian lepasan. Jakarta: Hipokrates; 2012.

Hidayat, Alimul. Aziz, 2009. Metode Penelitian Keperawatan Teknik Analisis Data, Jakarta.

Ibnu. 2014. Gambaran Masyarakat Tentang Penggantian Gigi Yang Hilang, Program Studi D-III Teknik Gigi STIKes Hang Tuah Pekanbaru.

Notoadmodjo, Soekidjo, 2005. Metodologi Penelitian Kesehatan, Jakarta.

Notoadmodjo, Soekidjo, 2012.Promosi Kesehatan dan Perilaku Kesehatan, Jakarta.

Laporan Hasil Riset Krsrhatan Dasar (Riskesdas) Nasional. (2013). Badan Penelitian dan pengembangan 
kesehatan. Depertemen Kesehatan dan Kesehatan Republik Indonesia.

Laporan Hasil Riset Kesehatan Dasar (Riskesdas) Provinsi Riau (2013). Badan Penelitian dan pengembangan kesehatan Kementrian esehatan RI.Fakultas Kedokteran Gigi Universitas Sam Ratulangi Manado.

Saryono, 2011. Metodologi Penelitian Kesehatan, Jogjakarta.
Sugiono, 2009. Metode Penelitian Kuantitatif Kualitatif dan $R$ dan D, Bandung.

Sujarweni, Wiratna. V, 2014. Metodologi Penelitian, Yogyakarta.

Titjo, Oliavia. Charisma, 2014. Perilaku penggunaan gigi tiruan lepasan di kelurahan bahu. Fakultas Kedokteran Gigi Universitas Sam Ratulangi Manado. Wikipedia, (2006). Gigi Palsu. http://id.wikipedia.org/Gigi.Palsu.

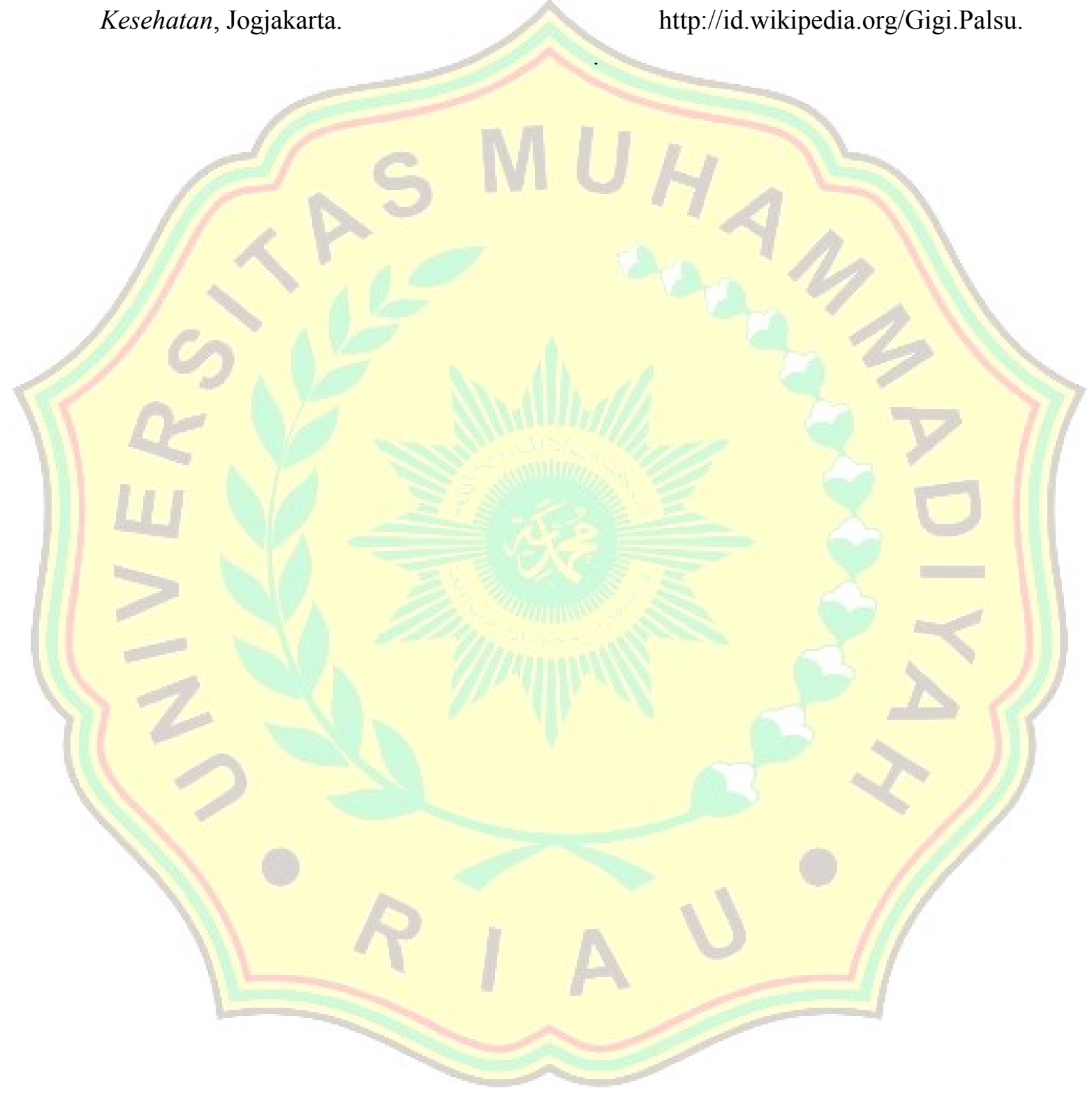

